\title{
Mathematical model in assesment of saltwater intrusion in Saigon - Dong Nai river system (Southern Vietnam) due to sea level rise
}

- Ho Chi Thong

- Dau Van Ngo

- Le Song Giang

- Tran Thi Phi Oanh

University of Technology, VNU-HCM

Manuscript Received on ,August 29 $9^{\text {th }}, 2014$; Manuscript Revised November $11^{\text {th }}, 2014$ )

\section{ABSTRACT:}

SaiGon -DongNai (SG-DN) river system plays a vital role in developing the southern key economic triangle including Ho Chi Minh City, DongNai and BinhDuong provinces. Saltwater intrusion results from many factors and complex movements in SG-DN river system, in the midst of which are sea level rise and water regulation of upstream reservoirs. Theses causes have gradually changed the hydraulic regimes of the river system. As a result, saltwater intrusion has become seriously. In this article, the authors used mathematical models to investigate the change of saltwater boundary of the river system before and after the impact of sea level rise and the regulatory regime of the reservoirs. The findings contributed to the predicted scenarios where sea level rise and salinity boundary could be controlled through the regulation of upstream reservoirs.

Keywords: sanility intrustion, sea-level rise, mathematical model.

\section{INTRODUCTION}

SG-DN river system includes DongNai river's mainstream and four major tributary rivers that are $\mathrm{La}$ Nga river, Be River, SaiGon River and Vam Co River. The SG-DN river basin is the home of many South East provinces and part of the highland provinces as well, with its total area about $40,000 \mathrm{~km}^{2}$.

Saline intrusion is an extremely important and more noticeable issue in the low basin of SG-DN river. As featuring a deep river bed, we have discovered that a gentle riverbed slope with high water level amplitude of daily tide leads to the rising tide of saltwater intrusion upstream, especially in the mid and late dry season (March and April). Particularly, in recent years, along with the impact of climate change and sea level rise, the calculations and predictions of saltwater intrusion have become more pressing. Many studies, therefore, have lately reflected substantial improvement by using mathematical methods and algorithms. These methods have given the simulation results almost close to the actual measured ones. Eventually, the prediction outcomes through mathematical calculations are reasonably accurate.

Implementation of computing saltwater intrusion in this article used software F28 (written and developed by Dr. Le Song Giang) with calculations based on the solution of differential equations describing motion of water in the environment by finite volume method, thereby ensuring the principle of conservation of mass and momentum. The results of this article have showed the salinity intrusion under the rising sea level effect with the participation of households in their irrigation

\section{Trang94}


upstream monitoring stations along the downstream river of the system.

\section{MODEL DECRIPTION}

\subsection{Method}

Flows and salt-water intrusion in SG-DN river system is calculated by the integration of onedimensional and two- dimensional models: the former for small rivers and canals. Flows and chemical transport of this model is described by Saint-Venant equations (1) (2) (Vreugdenhil,1989) and transport equations (3) :

$$
\begin{gathered}
\frac{\partial A}{\partial t}+\frac{\partial Q}{\partial s}=q_{l} \\
\frac{\partial Q}{\partial t}+\frac{\partial}{\partial s}\left(\frac{Q^{2}}{A}\right)+g A \frac{\partial \eta}{\partial s}+g A \frac{|Q| Q}{K^{2}}-V_{a} q_{l}=0
\end{gathered}
$$

Where $\eta$ - the water level; Q, A and $\mathrm{K}$ - the flow rate, the cross section area and the flow rate module for 1D flow. $q_{1}-$ lateral inflow per unit length of river; $V_{a}$ - axial component of velocity of lateral inflow of $q_{1}$ )

At the river nodes (Figure 1) where tributaries connect with each other, the preserve volume of water equations in the form of the integral is used:

$$
\frac{\partial W_{J}}{\partial t}+\sum_{i} Q_{i}=\sum_{i} \int_{L_{i}} q l_{i} d l
$$

Where $\mathrm{W}_{\mathrm{J}}$ - the volume of node $\mathrm{J} ; \mathrm{L}$ - the control contour of the node; and $\mathrm{q}_{\mathrm{n}}$ - the normal to the control contour component of flow rate per unit width.

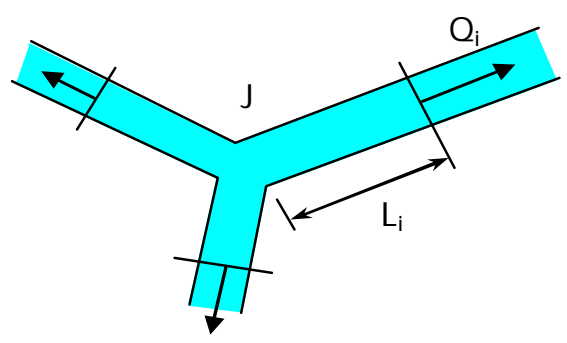

Fig.1: Node of river diagram

Mainstreams and estuaries are modeled in 2D model.

Flows and chemical transport model are described by shallow water equations (4) (5) and 2D transport equations (10)

$$
\begin{aligned}
& \frac{\partial \eta}{\partial t}+\frac{\partial q_{x}}{\partial x}+\frac{\partial q_{y}}{\partial y}=q_{v} \\
& \frac{\partial \mathbf{q}}{\partial t}+\frac{\partial f(\mathbf{q})}{\partial x}+\frac{\partial g(\mathbf{q})}{\partial y}=\mathbf{b}(\mathbf{q})
\end{aligned}
$$

Where $\eta$ - the water level; $\mathbf{q}=\left[q_{x}, q_{y}\right] T=D \mathbf{U}-$ the vector of flow rate per unit width in $2 \mathrm{D}$ flow; $\mathbf{U}=\left[u_{x}, u_{y}\right] T-$ the vector of depth-averaged velocity; D - the water depth; $\mathbf{F}(\mathbf{q})$ - the flux vector of flow rate per unit width; and $\mathbf{b}(\mathbf{q})$ - the vector of external forces.

The vectors of flux, $\mathbf{F}(\mathbf{q})$, and of external forces, $\mathbf{b}(\mathbf{q})$, have the forms:

$\mathbf{F}=\left[\begin{array}{l}f(\mathbf{q}) \\ g(\mathbf{q})\end{array}\right]=\left[\begin{array}{l}q_{x} \mathbf{U}-A_{H} D \partial \mathbf{U} / \partial x \\ q_{y} \mathbf{U}-A_{H} D \partial \mathbf{U} / \partial y\end{array}\right]$

$\mathbf{b}(\mathbf{q})=\left[\begin{array}{l}-g D \partial \eta / \partial x-\left(\tau_{b x}-\tau_{w x}\right) / \rho+f q_{y} \\ -g D \partial \eta / \partial y-\left(\tau_{b y}-\tau_{w y}\right) / \rho-f q_{x}\end{array}\right]$

Where $\mathrm{A}_{\mathrm{H}}$ - the eddy viscosity; $\mathrm{f}$ - Coriolis parameter; $\left(\tau_{\mathrm{wx}}, \tau_{\mathrm{wy}}\right)$ - the shear stress on water surface due to the wind; ( $\left.\tau_{b x}, \tau_{b y}\right)-$ the bottom stress;.

The bottom stress is calculated using Manning's formula:

$\left(\frac{\tau_{b x}}{\rho}, \frac{\tau_{b y}}{\rho}\right)=\frac{g n^{2}}{D^{1 / 3}} \sqrt{u_{x}^{2}+u_{y}^{2}}\left(u_{x}, u_{y}\right)$

While the eddy viscosity is calculated using Elder's formula (Hervouet, 2003):

$A_{H}=6 u * D$

Where $\mathrm{n}$ - the Manning's roughness coefficient; $u *$ - the bottom shear stress velocity. 


$$
\begin{aligned}
& \frac{\partial(D C)}{\partial t}+\frac{\partial}{\partial x}\left(q_{x} C\right)+\frac{\partial}{\partial y}\left(q_{y} C\right)= \\
& \frac{\partial}{\partial x}\left(\varepsilon_{H} D \frac{\partial C}{\partial x}\right)+\frac{\partial}{\partial y}\left(\varepsilon_{H} D \frac{\partial C}{\partial y}\right)+ \\
& D S_{C}+q_{v} C_{q v}
\end{aligned}
$$

Where $\mathrm{C}$ - average depth concentration of solutes or suspended; $\mathbf{q}=\left[q_{x}, q_{y}\right] T=D \mathbf{U}-$ the vector of flow rate per unit width in 2D flow; $\mathbf{U}=\left[u_{x}, u_{y}\right] T-$ the vector of depth-averaged velocity; D - the water depth; $\mathrm{q}_{\mathrm{v}}$ - lateral inflow per unit surface; $\varepsilon_{\mathrm{H}}$ - eddy diffusion coefficient; $\mathrm{C}_{\mathrm{qv}}$ - concentration in lateral inflow; $\mathrm{S}_{\mathrm{C}}$ source term, express speed production or destruction of dissolved (or suspended);

The vectors eddy diffusion coefficient $\varepsilon_{\mathrm{H}}$ have the forms:

$$
\varepsilon_{H}=\sigma \cdot A_{H}
$$

Where $\sigma$ - prandtl number; $\mathrm{A}_{H}$ - the eddy viscosity.

1D model and 2D model integated in common node, used a common water level and soveled from transport equations (3):

$$
\frac{\partial W_{J}}{\partial t}+\sum_{i} Q_{i}=\sum_{i} \int_{L_{i}} q l_{i} d l
$$

These basic equations are solved by finite volume method, in which the 2D mesh is non-structure with quadrangle elements.

\subsection{Model building}

\subsubsection{Channel network of river for computing}

SG-DN river system is modeled as a network with 195 compute nodes, 220 branches. The branches are divided into 1.496 sections, which lengths are approximately 1.000 meters, and 1.716 sections.
Mainstreams and estuaries are divided into 2D quadrilateral grid with 30.859 elements and 33.733 nodes.

River and sea bottom topography built from the base map and topographic map of SG-DN river system was created/drawn by Ho Chi Minh City People's Committee.

\subsubsection{Input parameters}

- Base map, topographic map of SG-DN river system.

- Coordinates of nodes and branches channel topology table, element.

- Coordinates cross-sections and shapes.

- Salinity over time.

- Sea level on planet steps of the model.

- Discharge flow of water reservoirs for irrigation in the basin.

\subsubsection{Boundary conditions:}

The flow of discharged reservoirs such as Dau Tieng, Tri An, Phuoc Hoa, Can Dang, Tan An and sea level at Vung Tau-Go Cong observation station are used as boundary conditions.

Salinity record at Vung Tau - Go Cong observation station when sea-water inflows is obtained using $34 \mathrm{~g} / \mathrm{l}$. This is an average salinity of the East Ocean.

The model has six important open boundaries. At the nodes of Tri An, Phuoc Hoa, Dau Tieng and Can Dang, the flow rates are given using measurement data. The measurement of water level is applied at Tan An node. At the boundary from Vung Tau to Go Cong, the water level is calculated from tidal constants.

\subsubsection{Data model:}

- Manning's roughness coefficient for the river section and the 2D model

\section{Trang96}




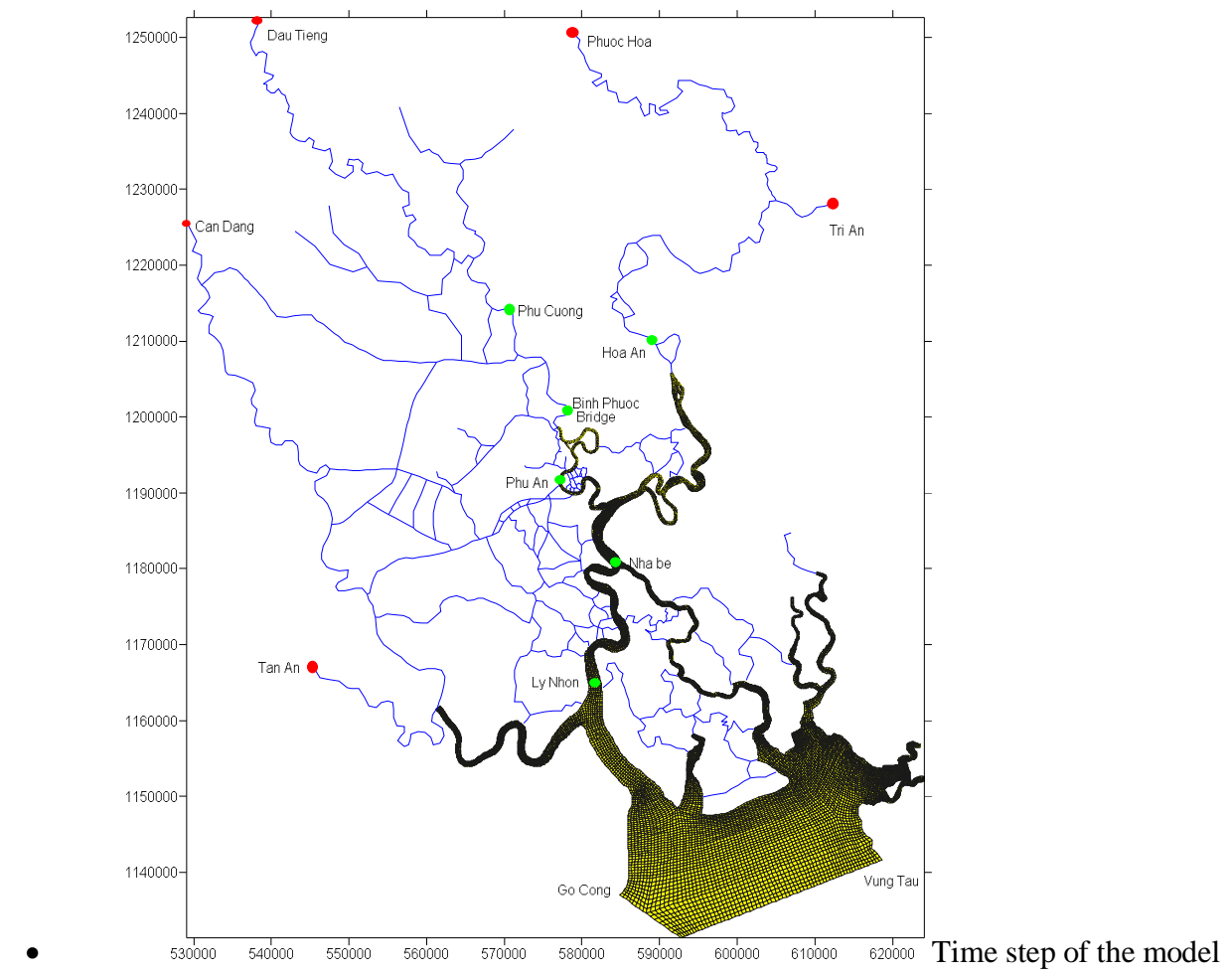

Fig.2 : The computational mesh and observation stations of SG-DN river system

\subsection{Model calibration}

\subsubsection{Water level calibration}

\begin{tabular}{|c|c|c|c|c|}
\hline Station & Node & ID section & $\begin{array}{c}\text { Initial } \\
\text { Manning's } \\
\text { roughness } \\
\text { coefficient }\end{array}$ & $\begin{array}{c}\text { Calibrated } \\
\text { Manning's } \\
\text { roughness } \\
\text { coefficient }\end{array}$ \\
\hline Bien Hoa & 186 & $164-186$ & 0.035 & 0.045 \\
\hline Ben Luc & 470 & $470-494$ & 0.034 & 0.02 \\
\hline Tan An & 495 & $495-528$ & 0.034 & 0.02 \\
\hline Phu An & 30084 & 11 & 0.025 & 0.035 \\
\hline Nha Be & 29490 & 10 & 0.02 & 0.033 \\
\hline
\end{tabular}

Calculated water level used to calibrate from 12.00 a.m. on March 1, 2012 to 12.00 a.m. on March 15, 2012. The are given in Table 1.

Table 1: Manning's roughness coefficient calibration
Manning's roughness coefficient (n) of the Equation (8) is the parameter of being calibrated. The results of Manning's roughness coefficient calibration

results of calibration for the observation stations are given in the figures below: 
Water level (m)

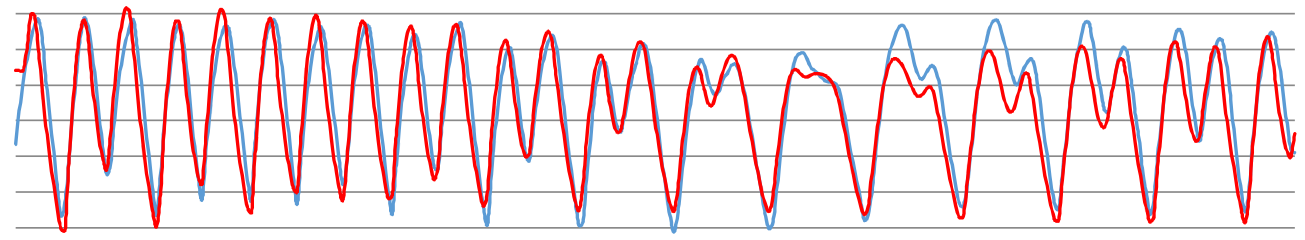

— Actual measured data Calculated data

Date

Fig. 3 : The results of water level calibration for the Bien Hoa observation stations

Water level (m)

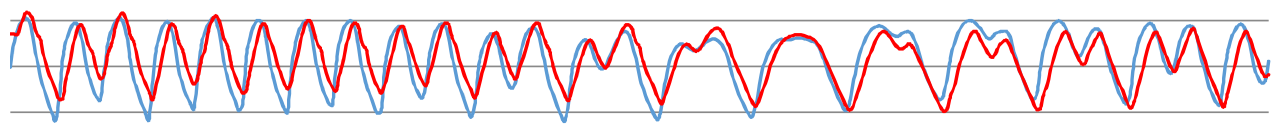

_ Actual measured data _Calculated data

Date

Fig. 4 : The results of water level calibration for the Ben Luc observation stations

Water level (m)

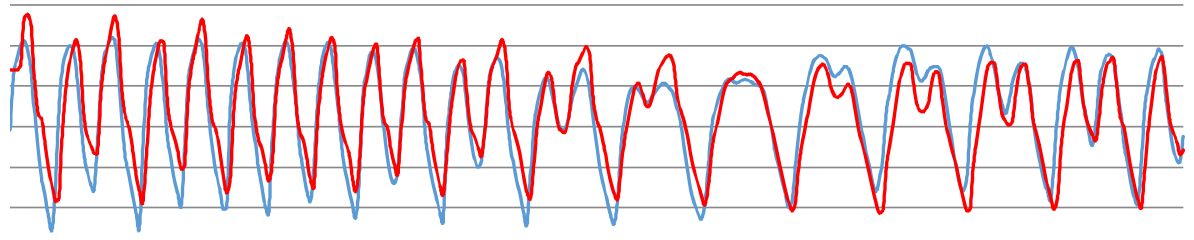

— Actual measured data Calculated data

Date

Fig. 5 : The results of water level calibration for the Tan An observation stations

Water level $(m)$

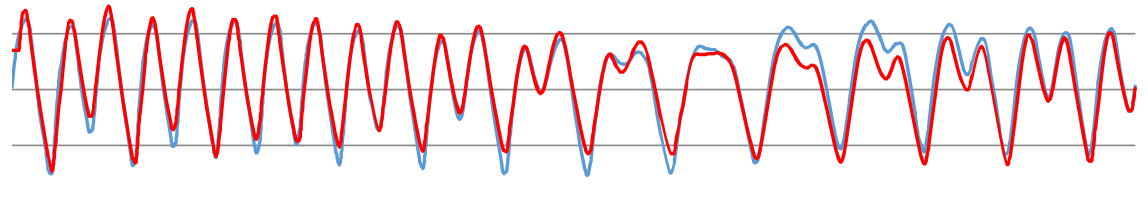

— Actual measured data _Calculated data

Date

Fig. 6 : The results of water level calibration for the Phu An observation stations

\section{Trang98}


Water level (m)

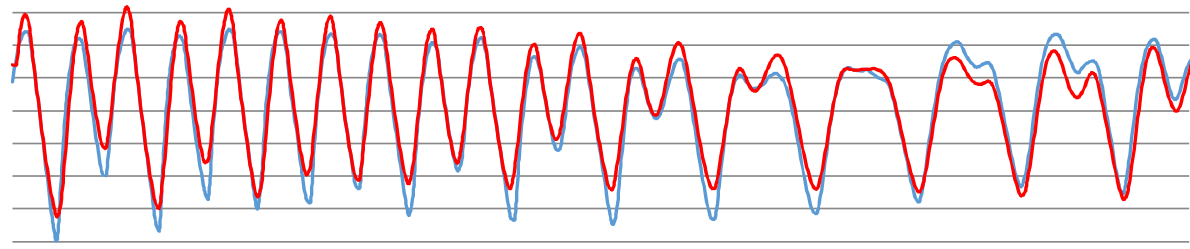

_ Actual measured data _Calculated data

Date

Fig. 7 : The results of water level calibration for the Nha Be observation stations

The comparison of calculated water level and actual water level measured at observation stations has proved that calculated water level amplitude is slightly smaller than the measured data in general, however it does provide a good analogy between the calculation and measurement results, and especially they appear in the same phase. (Figs. 3-7)

\subsubsection{Salinity calibration}

$\sigma$ - prandtl number of the Equation (11) is the parameter of being calibrated. Salinity used to calibrate from 12.00 a.m. on March 8, 2012 to 12.00 a.m. on March 16, 2012. The results of calibration for the observation stations are given in the figures below:

Concentration $(\mathrm{g} / \mathrm{l})$

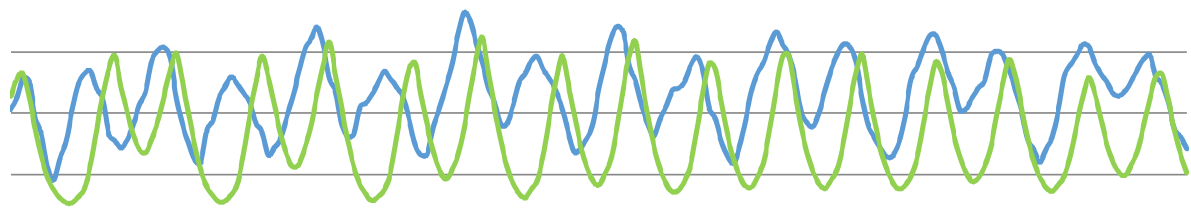

_ Actual measured data

Calculated data

Fig. 8. The results of salinity calibration for the Nha Be observation stations

Concentration $(\mathrm{g} / \mathrm{l})$

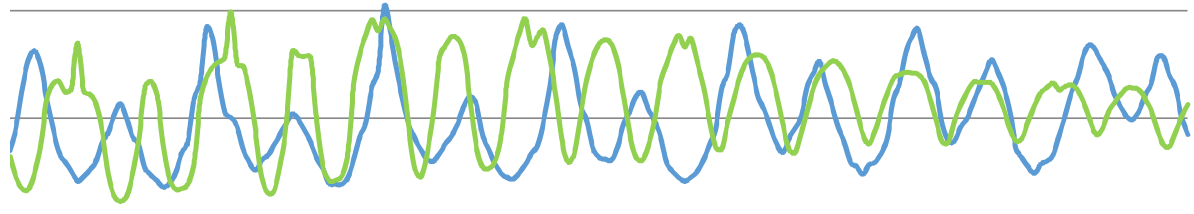

_ Actual measured data $\quad$ Calculated data

Fig. 9: The results of salinity calibration for the Phu An observation stations

Comparison of calculated salinity and actual measured salinity at observed stations shows that the calculated results have amplitude of oscillation higher than the measured data in general. Despite the little difference of phased similarity, the results are still accepted. (Figs. 8-9) 


\section{RESULTS AND DISCUSSION}

This article presents the results and reviews of the salinity change of SG and DN river systems. The change occurred in March, 2012 at monitoring stations such as Vung Tau, Nha Be, Cat Lai, Thu Thiem, and An Hoa, according to the scenario of sea level rising by respectively $15 \mathrm{~cm}, 30 \mathrm{~cm}, 50 \mathrm{~cm}, 70 \mathrm{~cm}$ compared to the average of sea level at Vung Tau station.

The results of salinity spread calculated by the model are displayed in Table 3.
Figs. 10-12 describe the correlation of sea level rising and salinity at observation stations. As the results in Tab.3, we find that when sea level rises, the salinity will spread deeply into the upstream of the river. According to the Figs. 10-12 we learn that salinity spread rates appear differently, in which Nha Be station is impacted the most powerfully with the slope ( $\mathrm{a}=$ 1.2778), the next one is Thu Thiem station with $\mathrm{a}=$ 0.9088 and Cat Lai station with $\mathrm{a}=0.9009$. However, Hoa An station is an important water resource for the city that has not been affected much with sea level rising by $75 \mathrm{~cm}$.

Tab 3. Water levels and salinity concentration sea level rising by respectively $15 \mathrm{~cm}, 30 \mathrm{~cm}, 50 \mathrm{~cm}, 75 \mathrm{~cm}$

\begin{tabular}{|c|c|c|c|c|c|c|c|c|c|c|}
\hline \multirow{3}{*}{ Station } & \multicolumn{2}{|c|}{ Delta $h=0 \mathrm{~m}$} & \multicolumn{2}{|c|}{ Delta $h=0.15 \mathrm{~m}$} & \multicolumn{2}{|c|}{ Delta $h=0.3 \mathrm{~m}$} & \multicolumn{2}{|c|}{ Delta $h=0.5 \mathrm{~m}$} & \multicolumn{2}{|c|}{ Delta $\mathrm{h}=0.75 \mathrm{~m}$} \\
\hline & $\begin{array}{l}\text { Water } \\
\text { level }\end{array}$ & $\begin{array}{c}\text { Concen- } \\
\text { tration }\end{array}$ & $\begin{array}{l}\text { Water } \\
\text { level }\end{array}$ & $\begin{array}{l}\text { Concen- } \\
\text { tration }\end{array}$ & $\begin{array}{l}\text { Water } \\
\text { level }\end{array}$ & $\begin{array}{c}\text { Concen- } \\
\text { tration }\end{array}$ & $\begin{array}{l}\text { Water } \\
\text { level }\end{array}$ & $\begin{array}{l}\text { Concen- } \\
\text { tration }\end{array}$ & $\begin{array}{l}\text { Water } \\
\text { level }\end{array}$ & $\begin{array}{l}\text { Concen- } \\
\text { tration }\end{array}$ \\
\hline & (m) & $(\mathrm{g} / \mathrm{l})$ & (m) & $(g / l)$ & (m) & $(\mathrm{g} / \mathrm{l})$ & (m) & $(\mathrm{g} / \mathrm{l})$ & (m) & $(\mathrm{g} / \mathrm{l})$ \\
\hline Vung Tau & $(0.178)$ & 34 & $(0.029)$ & 33.98 & 0.121 & 33.98 & 0.321 & 33.99 & 0.571 & 33.99 \\
\hline Nha Be & 0.974 & 9.576 & 1.108 & 12.54 & 1.295 & 13.26 & 1.505 & 14.23 & 1.740 & 15.12 \\
\hline Cat Lai & 1.136 & 2.860 & 1.306 & 4.72 & 1.467 & 5.124 & 1.658 & 5.919 & 1.900 & 6.764 \\
\hline $\begin{array}{l}\text { Thu } \\
\text { Thiem }\end{array}$ & 1.246 & 1.703 & 1.385 & 3.289 & 1.527 & 3.584 & 1.707 & 4.503 & 1.931 & 5.64 \\
\hline Hoa An & 1.395 & 0.003 & 1.499 & 0.008 & 1.604 & 0.01076 & 1.752 & 0.01782 & 1.948 & 0.03029 \\
\hline
\end{tabular}

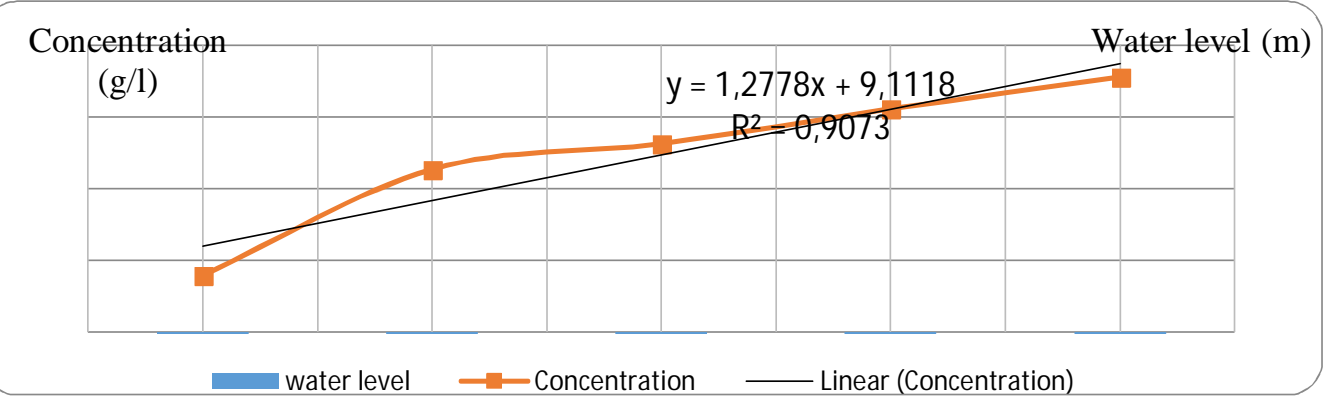

Fig. 10. The correlation of water level and salinity intrusion at Nha Be observation station

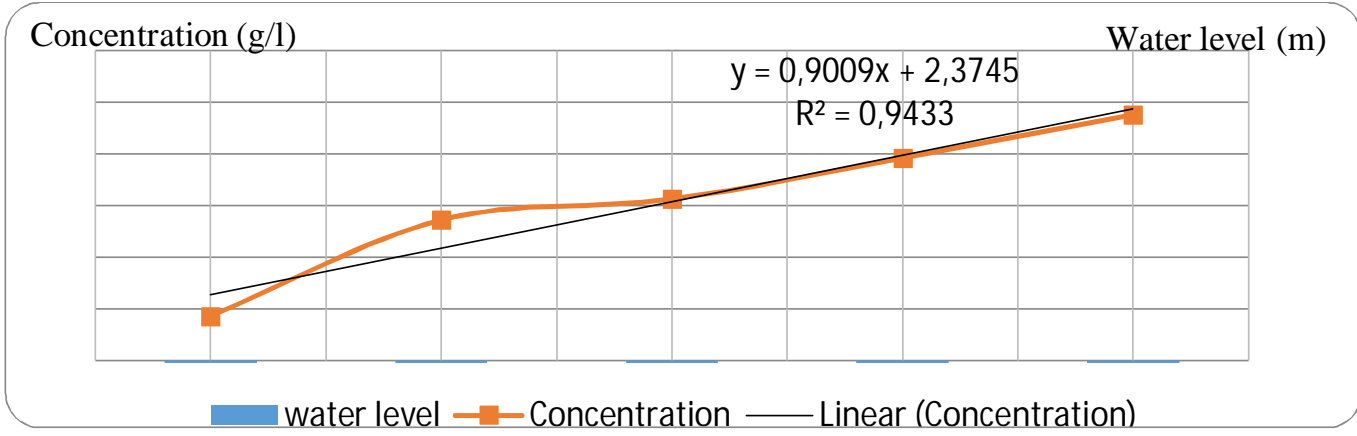

Fig. 11. The correlation of water level and salinity intrusion at Cat Lai observation station

\section{Trang 100}




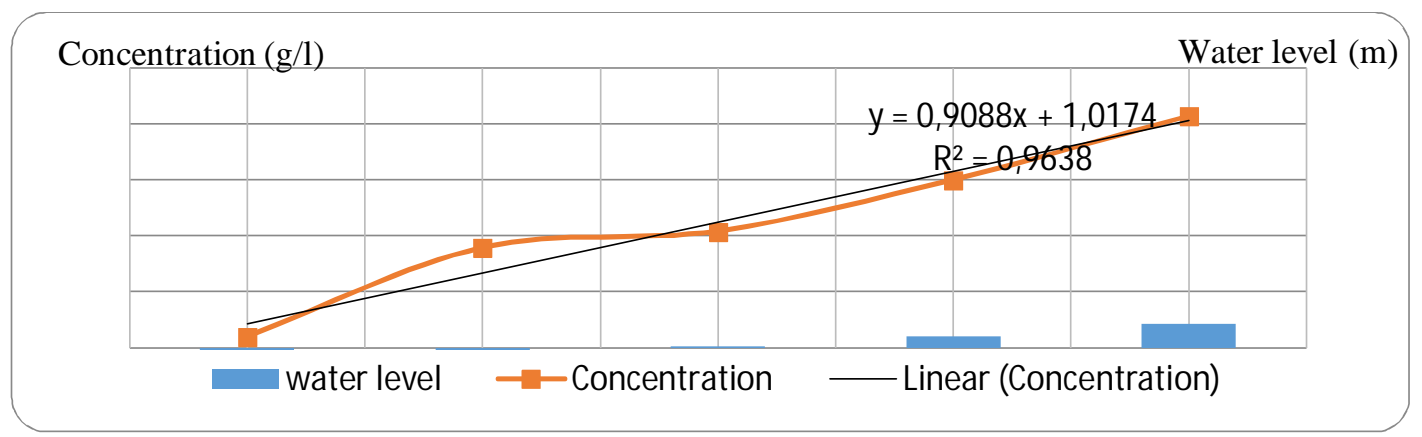

Fig. 12. The correlation of water level and salinity intrusion at Thu Thiem observation station

\section{CONCLUSION}

Results of water level calculated by the model reflects that the amplitude slightly smaller in comparison to the real measurement data, but the calculated salinity with the amplitude of oscillation is higher. Of the similarity phase, the calculated water levels have a coincident phase and fairly parallel between model results and measured water level results, but the calculated salinity just has a little difference. Through an examination of saltwater intrusion by sea level rising respectively $15 \mathrm{~cm}, 30 \mathrm{~cm}, 50 \mathrm{~cm}$ and 75 $\mathrm{cm}$, the vibration amplitude in salinity has been measured at the stations near $300 \%$, but Hoa An station considered as a main water supply has not been affected. On the other hand, it is also recognized that salinity regime of the basin downstream of SG-DN is quite sensitive to hydraulic river mode. Therefore, we can also rely on water regulation of upstream irrigation lake to improve salinity mode and to regulate the distribution of salinity in the downstream river.

\section{Ứng dụng mô hình toán trong đánh giá xâm Nhập mặn của hệ thống sông Sài Gòn - Đồng Nai dưới tác động của nước biển dâng}

- Hồ Chí Thông

- Đậu Văn Ngọ

- Lê Song Giang

- Trần Thị Phi Oanh

Trường Đại học Bách khoa, ĐHQG-HCM

\section{TÓM TÁT:}

Hệ thống sông Sài Gòn-Đồng Nai đóng một vai trò quan trọng trong việc phát triển của tam giác kinh tế trọng điểm phía Nam bao gồm thành phố Hồ Chí Minh và các tỉnh Bình Dương, Đồng Nai. Quá trình xâm nhập mặn ở hệ thống sông Sài Gòn - Đồng Nai phụ thuộc vào nhiều yếu tố và diễn biến khá phức tạp. Một trong những yếu tố quan trọng và ảnh hưởng rất lớn tới quá trình xâm nhập mặn chính là chế độ thủy lực và sự điều tiết nước của các hồ thủy lợi ở thượng lưu. Mặt khác, dưới tác động của biến đổi khí hậu và nước biển dâng cũng làm xâm nhập mặn trở nên nghiêm trọng. 
Trong bài viết này, tác giả sử dụng mô hình toán để nghiên cứu sự thay đổi ranh giới mặn của hệ thống sông trước và sau khi tác động của nước biển dâng và các chế độ điều tiết của các hồ chứa.
Kết quả của bài báo này góp phần với các kịch bản dụ̂ báo nơi nước biển dâng và ranh giới mặn có thể được kiểm soát thông qua sự điều tiết của các hồ chứa thượng nguồn.

Từ khóa: xâm nhập mặn, nước biển dâng, mô hình toán.

\section{TÀI LIỆU THAM KHẢO}

[1]. Ngo Dau Van, "Calculation of salty intrustion in the Dong Nai river system", Geological Journals Department of Geology and Minerals of Vietnam, (Vol 7-8 / 2007, No. 301, pp76-82),2007.

[2]. Amin M, "Changing mean sea level and tidal constants on the West coast of Australia", Autralian Journal of Marine and Freshwater Reseach, (44(6): 911-999), 1993.

[3]. Ferla M., Cordella M., Michielli L., Rusconi A."Long-term variations on sea level and tidal regime in the lagoon of Venice, Estuarine",
Coastal and Shelf Science, (Volume 75, Issues 12, p.214-222), October 2007.

[4]. Giang Le Song, "Building computational models for integrated urban drainage calculations, The summary report the results of scientific and technological themes available HCM city Vietnam Nation University, November 2010.

[5]. Hydrometeorological Observatory Southern region (2013), Data of observed stations in Sai Gon - Dong Nai river.

\section{Trang 102}

